\title{
Infected transverse colonic cystic duplication simulating pelvic appendicular abscess
}

\author{
Ramnik V Patel, ${ }^{1,2}$ Irene Milliken, ${ }^{3}$ Alistair Dick, ${ }^{3}$ David Marshall ${ }^{3}$
}

${ }^{1}$ Department of Paediatric Urology, University College London Hospitals NHS Foundation Trust, London, UK ${ }^{2}$ Department of Paediatric Urology, Great Ormond Street Children Hospital NHS Trust, London, UK

Department of Paediatric Surgery, The Royal Belfast Hospital for Sick Children, Belfast, UK

Correspondence to Ramnik V Patel,

ramnik@doctors.org.uk
To cite: Patel RV, Milliken I, Dick A, et al. BMJ Case Rep Published online: [please include Day Month Year] doi:10.1136/bcr-2013201459

\section{DESCRIPTION}

A 23-month-old girl presented with 5 days of lower abdominal pain, lethargy, anorexia, reduced wet nappies and high fever not responding to a 5 -day course of amoxicillin. On examination, she had a pulse rate of 179 , respiratory rate 32 , temperature $39.2^{\circ} \mathrm{C}$ and a tender mass in the lower abdomen. A urine dipstick was normal. White cell count was $30.36 \times 10^{9} / \mathrm{L}$, neutrophils $24.59 \times$ $10^{9} / \mathrm{L}$ and C reactive protein $34.9 \mathrm{mg} / \mathrm{L}$. An abdominal ultrasound scan showed a $5.7 \mathrm{~cm}$ long cystic mass on the left side of the pelvis with a thin septae, layering of the debris within the mass, haustra-like appearance and enhancing double wall at places, and a small amount of free intraperitoneal fluid in the pelvis, which was later confirmed by a CT scan (figure 1). A giant infected cystic duplication of the mid-transverse colon was diagnosed at surgery via Pfannenstiel incision. She underwent a segmental resection of the transverse colon including the duplicated colon and end-to-end anastomosis uneventfully. Pathology confirmed non-communicating infected colonic duplication cyst and revealed a whole muscle layer of the colon together with inflamed, ulcerated mucosa with extensive granuloma and abscess formation compatible with an infected duplication. Postoperative recovery was uneventful. She is asymptomatic and thriving well at 8-month follow-up. Mid-transverse colonic cystic duplication presenting late with complications of infection and abscess formation in the pelvis is rare. ${ }^{1}{ }^{2}$ Differential diagnoses include appendicular abscess, infected ovarian cyst, inflammatory pseudocyst or infected mesenteric cyst. Antenatal diagnosis is possible and resection with reconstruction is curative. ${ }^{3}$ Transverse colonic surgery via Pfannenstiel incision is a technical challenge.
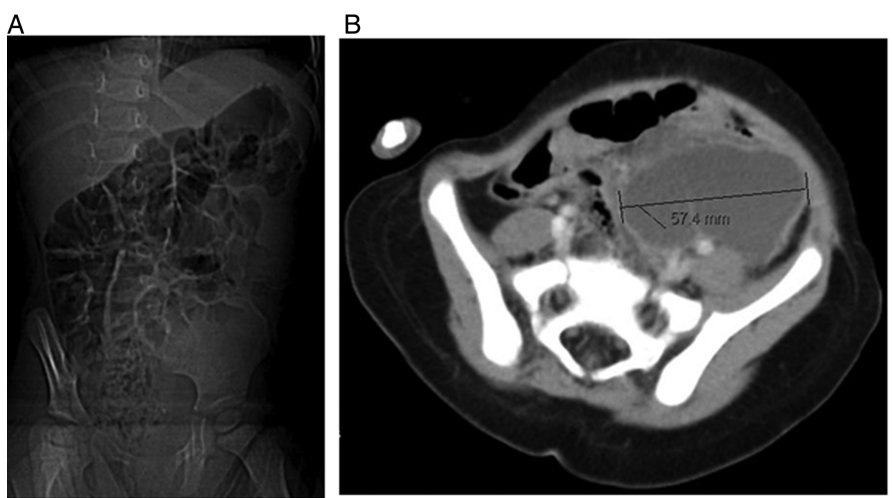

C
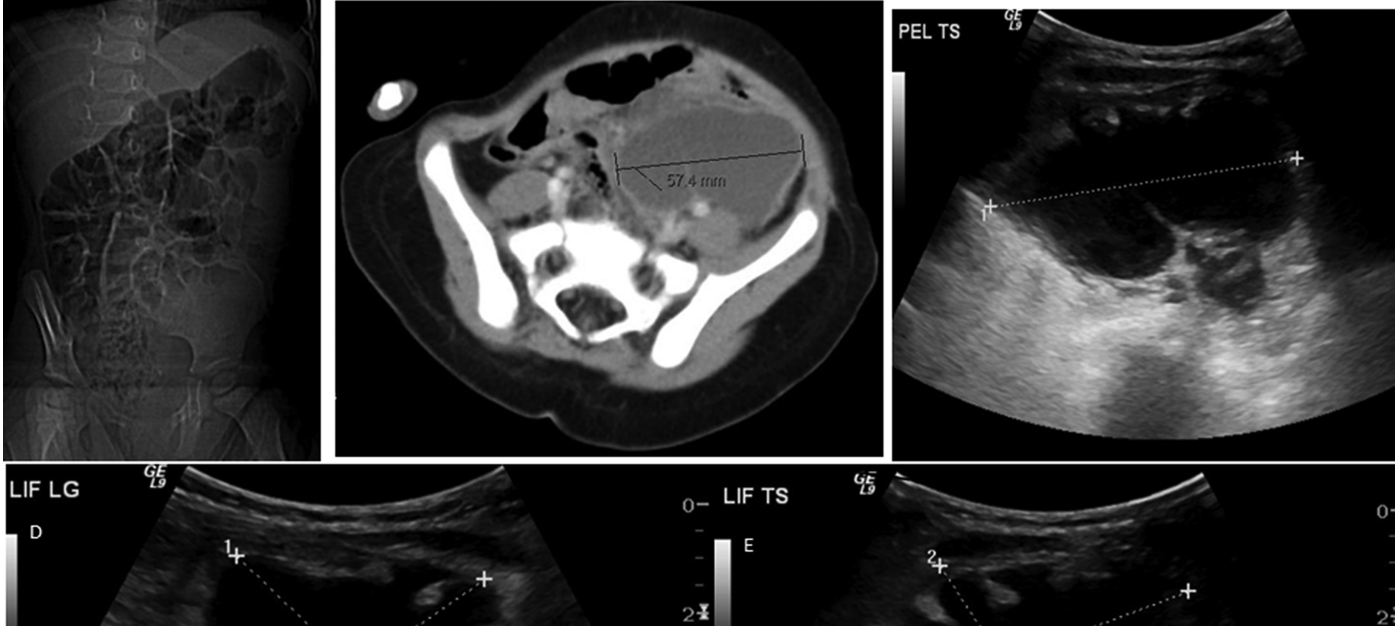


\section{Learning points}

- Transverse colonic tubular duplications are common but cystic duplications are rare. Since the transverse colon is mobile, cystic duplications of the mid-transverse colon can present in the pelvis.

- An infected transverse colonic cystic duplication cyst can mimic appendicular abscess with lower abdominal pain and fever associated with tender mass and raised inflammatory markers. The classic enhancing mucosa of a duplication cyst on ultrasound/CT scan can be destroyed by infection and an important clue may be lost.

- Colonic duplications have a high incidence of complications, such as infection, bleeding, perforation, adenocarcinoma and obstruction, and therefore, even if antenatally diagnosed or incidentally found, should be resected.
Contributors All the authors have actively participated in the clinical management of this patient and have been involved in the preparation, editing and finalisation of the manuscript.

Competing interests None.

Patient consent Obtained.

Provenance and peer review Not commissioned; externally peer reviewed.

\section{REFERENCES}

1 Banchini $F$, Delfanti $R$, Begnini $E$, et al. Duplication of the transverse colon in an adult: case report and review. World J Gastroenterol 2013;19:586-9.

2 Stefanidis K, Lappas I, Kolofousi C, et al. A rare presentation of colonic duplication cyst: report of a case and review of literature. JBR-BTR 2012;95:71-3.

3 Piolat $C, N^{\prime}$ Die J, Andrini P, et al. Perforated tubular duplication of the transverse colon: a rare cause of meconium peritonitis with prenatal diagnosis. Pediatr Surg Int 2005;21:110-12.

Copyright 2013 BMJ Publishing Group. All rights reserved. For permission to reuse any of this content visit http://group.bmj.com/group/rights-licensing/permissions.

BMJ Case Report Fellows may re-use this article for personal use and teaching without any further permission.

Become a Fellow of BMJ Case Reports today and you can:

- Submit as many cases as you like

- Enjoy fast sympathetic peer review and rapid publication of accepted articles

- Access all the published articles

- Re-use any of the published material for personal use and teaching without further permission

For information on Institutional Fellowships contact consortiasales@bmjgroup.com

Visit casereports.bmj.com for more articles like this and to become a Fellow 